\title{
Program Bimbingan Karir Untuk Meningkatkan Kemauan Kerja Siswa Kesetaraan Paket C di Kota Serang
}

\author{
Galuh Mulyawan1, Dede Rahamat Hidayat², Aip Badrujaman ${ }^{3}$ \\ 1,2,3Universitas Negeri Jakarta \\ ${ }^{3}$ Program Studi Bimbingan dan Konseling, Fakultas Ilmu Pendidikan, Universitas Negeri Jakarta \\ e-mail: galuhmulyawan bk17s2@mahasiswa.unj.ac.id
}

\begin{abstract}
Non-formal education especially equality education was born to help people who cannot enjoy formal education and belong to disadvantaged communities, students in non-formal education especially equality education have several problems from the results of filling in the tools revealed by common problems conducted at three equality education institutions in Serang City, out of the 10 items of statement there are 3 items that are the highest, namely the highest problems are career and work, the next 84\% are personal problems of 35\% and education and learning by 38\%. From the results of the tool revealed common problems known that one of the most The main thing in equality education in Serang City is a career problem, a career guidance program is made that is in accordance with the characteristics of equality students to improve the willingness of students to work, Work volition is a perceived capacity to create career choices although there are obstacles from the pretest results it is known that the total score obtained is 2534 after the career guidance has been carried out an increase of 216 points to 2750 this shows that career guidance programs for equality students can increase work will
\end{abstract}

Keywords: careerguidance, work volition

\begin{abstract}
Abstrak
Pendidikan nonformal khususnya pendidikan kesetaraan lahir untuk membantu masyarakat yang tidak dapat menikmati pendidikan formal, siswa pendidikan kesetaraan memiliki beberapa permasalahan dari hasil alat ungkap masalah yang dilakukan pada dua lembaga pendidikan kesetaraan paket C diKota Serang, dari 10 item pernyataan terdapat 3 item yang tertingi yaitu permasalahan yang paling tinggi adalah karier dan pekerjaan 84\% selanjutnya adalah permasalahan diri pribadi sebesar 35\% dan pendidikan dan pelajaran sebesar 38\%, Dari hasil alat ungkap masalah diketahui bahwa salah satu permasalahan yang dominan dalam pendidikan kesetaraan paket C di Kota Serang adalah permasalahan karir, dirancanglah program bimbingan karir yang sesuai dengan karakteristik siswa kesetaraan untuk meningkatkan kemauan kerja pada siswa, Kemauan kerja (work volition) ,dari hasil pretest diketahui skor total yang diperoleh adalah 2534 setelah dilaksanakan bimbingan karier terjadi peningkatan sebesar 216 point menjadi 2750 hal ini menunjukan bahawa program bimbingan karir bagi siswa kesetaraan paket $C$ dapat meningkatkan kemauan kerja
\end{abstract}

Kata kunci: bimbingan karir, kemauan kerja, pendidikan kesetaraan

\section{PENDAHULUAN}

Terdapat tiga jalur pendidikan di Indonesia seperti yang terdapat dalam Undang-Undang Nomer.20 Tahun 2003 Tentang sistem pendidikan nasional pasal 13 ayat 1 dikatakan bahwa jalur pendidikan terdiri dari pendidikan formal, pendidikan nonformal, dan pendidikan informal yang saling melengkapi dan memperkaya, namun dalam praktiknya pendidikan formal merupakan pendidikan yang menjadi prioritas utama dibandingkan dengan dua jalur pendidikan lainnya yaitu pendidikan nonformal dan informal sehingga pendidikan nonformal khususnya dalam jenis pendidikan kesetaraan (equivalency education) baik itu kesetaraan paket A yang setara dengan Sekolah Dasar (SD), kesetaraan paket B yang setara dengan Sekolah Menengah Pertama (SMP) dan kesetaraan paket C yang setara dengan Sekolah Menengah Atas (SMA).

Pendidikan nonformal atau pendidikan luar sekolah menurut Pasal 1 ayat 2 berfungsi sebagai pengganti, penambah dan juga sebagai pelengkap dari pendidikan formal hal itu juga sejalan dengan pendapat (Asran, 2011) menurutnya jalan alternatef untuk memecahkan 
permasalahan angka putus sekolah adalah salah satunya pendidikan nonformal baik yang diselenggarakan oleh pemeritah melalui sanggar kegiatan belajar (SKB) ataupun yang diselenggarakan oleh perseorangan atau kelompok seperti pusat kegiatan belajar masyarakat (PKBM) guna menjalankan program pemerintah wajib belajar dua belas tahun yang artinya setiap individu wajib mengikuti pendidikan hingga setara sekolah mengengah atas (SMA) seperti yang tercantum dalam peraturan menteri pendidikan dan kebudayaan republik indonesia nomor 19 tahun 2016 tentang program indonesia pintar pasal 2

Pendidikan nonformal khususnya pendidikan kesetaraan lahir untuk membantu masyarakat yang tidak dapat menikmati pendidikan formal dan tergolong kedalam masyarakat yang tidak beruntung (socially disadvantaged Communitie), masyarakat yang tidak dapat menikmati pendidikan formal baik itu putus sekolah ataupun tidak dapat bersekolah dipengaruhi dengan berbagai faktor menurut studi pendidikan alternatif bagi pemuda putus sekolah (LP3ES), (Asran, 2011): (a) anak didik itu sendiri orang tua (b) sistem persekolahan (c) lingkungan sosial peserta didik (d) alokasi yang keliru tentang sumber-sumber pendidikan (e) hubungan timbal balik diantara berbagai sebab yang sangat kompleks.

Permasalahan siswa pada pendidikan nonformal khusunya pendidikan kesetaraan tidak hanya yang disebutkan sebelumnya, tetapi juga dalam bidang akademis dan individu siswa pendidikan kesetaraan memiliki berbagai permasalahan, dari hasil pengisian alat ungkap masalah (AUM) umum yang dilakukan pada tiga lembaga pendidikan kesetaraan paket C di Kota Serang, dari 10 item pernyataan terdapat 3 item yang tertingi yaitu permasalahan yang paling tinggi adalah karier dan pekerjaan (KDP) $84 \%$ selanjutnya adalah permasalahan diri pribadi (DPI) sebesar $35 \%$ dan pendidikan dan pelajaran (PDP) sebesar 38\%, hal ini terdapat kesamaan permasalahan yang terjadi pada siswa pendidikan formal menurut (Yuliansyah \& Jarkawi, 2019) terdapat permasalah pribadi, sosial, belajar maupun karir pada siswa.

Dari hasil alat ungkap masalah (AUM) umum diketahui bahwa salah satu permasalahan yang paling utama dalam pendidikan kesetaraan paket $C$ di Kota Serang adalah permasalahan karier, kurangnya pengetahuan dan informasi tentang karier membuat siswa merasa kebingungan dalam perencanaan kariernya ditambah siswa yang berasal dari kelas ekonomi menengah kebawah mengalami permasalahan dalam menentukan karier, Pramudi, (2015) menyatakan faktor ekonomi keluarga menyebabkan pilihan karir siswa menjadi terhambat yaitu siswa kebanyakan tidak bisa memutuskan pilihan karirnya dengan memasuki pendidikan yang lebih tinggi, hal ini lah yang mempengaruhi siswa pada kemauan kerja (work volition) yang akan mereka hadapi.

Kemauan kerja (work volition) merupakan kapasitas yang dirasakan untuk membuat pilihan karier meskipun terdapat kendala (Duffy, Diemer, \& Jadidian, 2012), secara garis besar kemauan adalah kekuatan atau kapasitas dalam memilih dan memutuskan karier pada setiap individu, namun dalam setiap pengambilan keputusan selalu ada yang dinamkan dengan limitasi (keterbatasan) tertentu dalam setiap individu, keterbatasan pertama di batasi oleh pengetahuan dan alternative yang ada pada individu, keterbatasan kedua yaitu lingkungan dimana tempat individu berada sangat menentukan dalam mengambil keputusan, keterbatasan ketiga keputusan dibatasi oleh apa yang ingin dikerjakan individu.

Hambatan atau kendala dalam kemauan kerja (work volition) dapat di artikan sebagai faktor yang secara negatif dapat mempengaruhi karier seseorang (Blustein, 2006)Hambatan yang tinggi pada individu dapat mempengaruhi berbagai masalah, seperti identitas kejuruan (vocational identity), kematangan karier (career maturity), kepuasan karier (career satisfaction), dan kemampuan beradaptasi karier (career adaptability (Jadidian \& Duffy, 2012)

Dari analisis dibagain atas dapat disimpulkan bahwa siswa kesetaraan paket $\mathrm{C}$ di kota serang perlu mendapatkan pengarahan agar mendapatkan pencerahan dalam hal karir khusunya dalam kemauan kerja, karna dalam pendidikan kesetaraan sendiri layanan bimbingan konseling belum masuk pada ranah pendidikan nonforml khusunya pendidikan kesetaraan, tujuan dari penelitian ini adalah memberikan pengetahuan yang bertujuan untuk meningkatkan kemauan kerja siswa dengan metode bimbingan klasikal dikelas menurut (Walgito, 2005) dengan bimbingan karir siswa dapat membedakan lebih terperinci sifat-sifat kepribadiannya (kemampuan, bakat khusus, minat, nilai, dan sifat-siafat kepribadiannya) dan 
mampu melihat perbedaanya dengan orang lain. Selanjutnya ia dapat mengidentifikasi daerah dan tingkatan pekerjaan yang luas yang mungkin sesuai dengan dirinya.

\section{METODE}

Metode dalam program ini menggunakan metode eksperimen dengan menggunakan desain one group pretest-posttest yaitu melakukan pengukuran antara pretetst dan posttetst dengan objek yang sama yaitu pada siswa kesetaraan paket $\mathrm{C}$

Dalam eksperimen melibatkan siswa kesetaraan paket C di dua tempat yaitu Sanggar kegiatan belajar kota serang dan Pusat kegiatan belajar masyarakat Kartika, sample dalam penerapan program ini berjumlah 48 siswa dengan pembagian menurut jenis kelamin laki laki berjumlah 28 dan jenis kelamin perempuan berjmulah 20 siswa. Dalam tahapan pretest dan posttest pengabdi menggunakan work volition scale yang terdiri dari 16 pertanyaan tertutup dengan memiliki 7 pilihan jawaban, setelah dilakasanakan pretest selanjutnya yaitu pemberian treatment berupa layanan bimbingan karir pada siswa kesetaraan paket $C$, dan dilakukan kembali pengukuran setelah tahap pemberian treatment dilakukan (posttest)

\section{HASIL DAN PEMBAHASAN}

Pengabdian pada masyarakat kali ini dilaksanakan sebanyak dua kali pertemuan dalam seminggu, dalam setiap sesi dilaksanakan tiga pemberian materi dengan jumlah materi yang di berikan sebanyak 14 materi, Pada kegiatan awal dilaksanakan proses pengarahan dan penjelasan tentang maksud dan tujuannya program bimbingan karir ini pada siswa kesetaraan paket $C$ hal ini dilakukan untuk menyesuiakan kondisi kelas dan juga menjelaskan tahapan tahapan yang akan dilakukan selama program ini dilaksanakan karna dalam pendidikan nonformal dalam hal ini pendidikan kesetaraan layanan bimbingan karir ataupun layanan yang berkaitan dalam bimbingan konseling belum masuk pada ranah pendidikan nonformal (Mulyawan, 2020)

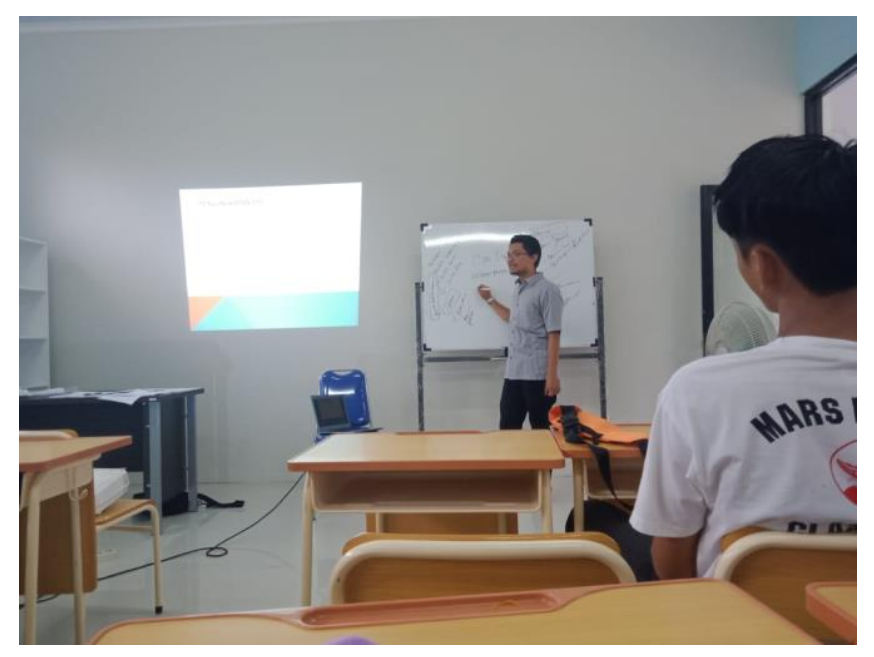

Gambar 1 proses peneraan program

Selanjutnya masuk dalam tahapan pretest dalam tahapan ini diketahui skor total kemauan kerja siswa sebesar 2750 dan rata-rata kemauan kerja siswa berada pada taraf rendah artinya dengan diaadakannya bimbingan karir yang dilakukan peneliti sangat tepat dengan kesesuaian permasalahan yang terjadi pada pendidikan kesetaraan paket $C$, setelah dilaksanakan pretest masuk pada pemberian materi yang dilakukan oleh pengabdi, dalam setiap materi yang diberikan dan pada saat akan masuk dalam materi selanjutnya diselingi dengan dilaksanakan ice breaking berupa peregangan tubuh maupun sorak sorak atau yel-yel 
bersemangat menurut (Faruqi, 2016) dengan menyisipkan ice breaking pada proses pembelajaran siswa cukup berpengaruh bagi peningkatan daya serap siswa, ice breaking juga bertujuan untuk mengembalikan fokus siswa pada materi yang akan diberikan selanjutnya.

Dalam pemberian materi pengabdi juga memberikan materi dengan menggunakan media yang bertujuan untuk menarik fokus dan minat pada siswa, media yang digunakan berupa media permainan berupa puzzle dan media film pendek sebagai media pemberian materi pada siswa, (Anam, 2015) penggunaan media yang menarik dalam pembelajaraan dapat meningkatan minat belajar pada siswa.

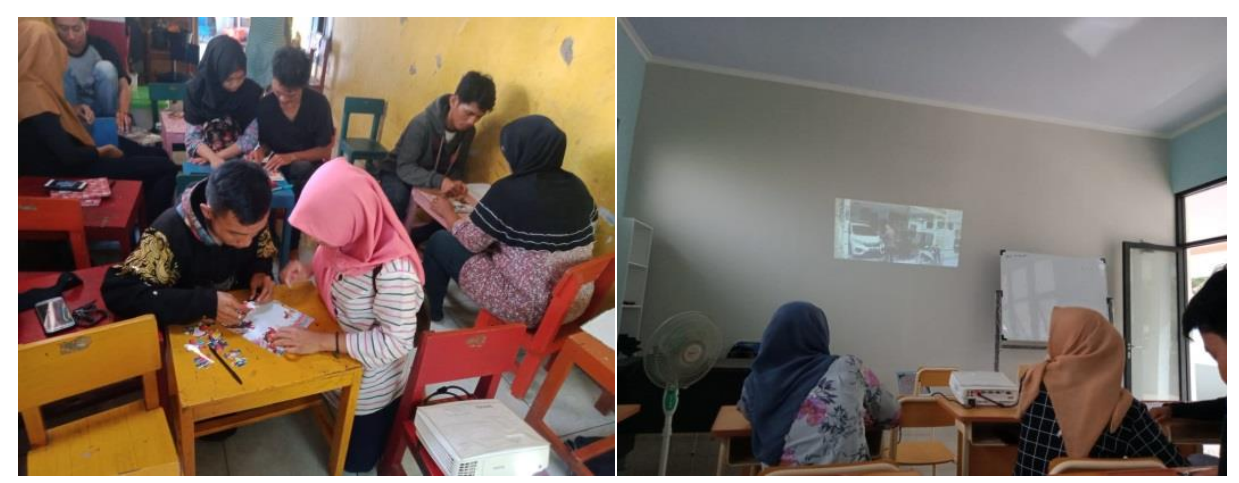

Gambar 2 penggunaan media dalam pemberian materi

Setelah proses pemberian materi siswa diminta untuk mengerjakan tugas yang berkaitan dengan materi yang diberkan hal ini juga sebagai bahan evaluasi dalam setiap materi yang telah diberikan oleh pengabdi pada siswa.

Setelah proses pemberian materi selanjutnnya masuk pada tahapan posttest hal ini bertujuan untuk mengetahui kemauan kerja (work volition) siswa apakah terjadi peningkatan atau tidak setelah dilaksanakan pemberian treatment berupa layanan bimbingan karir, dari hasil skor yang diperoleh setelah dilaksanan posttest terjadi peningkatan skor pada siswa sebesar 216 point menjadi 2750 yang semula skor kemauan kerja siswa sebesar 2534 hal ini dapat dilihat pada gambar 3 diagram dibawah

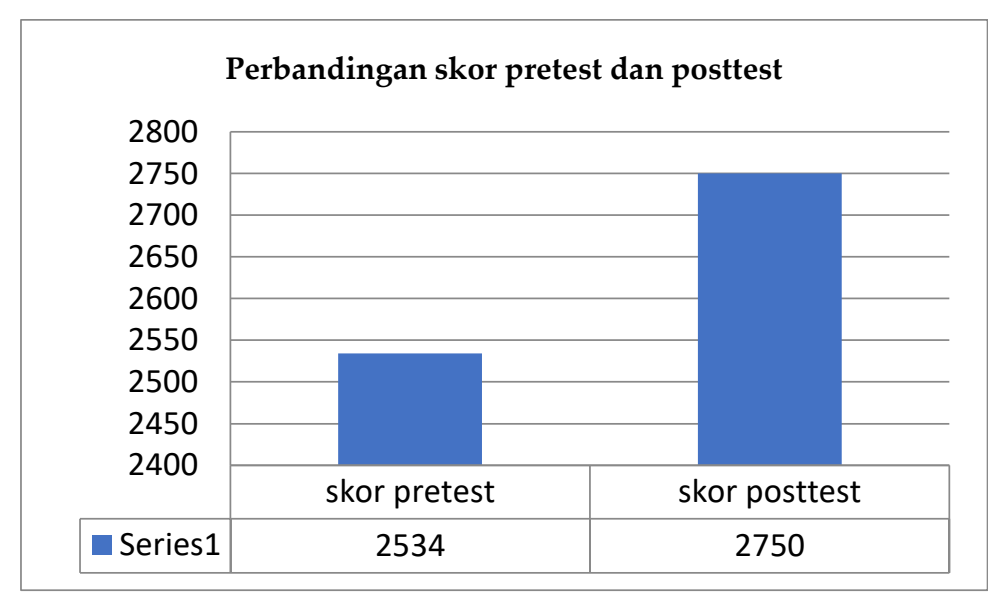

Gamabr 3 perbandingan skor sebelum dan sesudah dilakukan treatment

\section{Kesimpulan}

Pelakasanaan program bimbingan karir berjalan dengan lancer sampai dengan tahap akhir, program bimbingan karir bagi siswa kesetaraan paket $\mathrm{C}$ berdamapak positive bagi peningkatan kemauan kerjas siswa hal ini dapat dilihat dengan terjadi peningkatan skor pada sebelum dan sesudah dilaksanakannya program, pengabdian ini dijuga menjadi kontribusi dan 
sebuah terobosan baru dalam dunia pendidikan nonformal dengan diterapkannya layanan yang berkaitan dengan layanan bimbingan konseling, karna selama ini layanan bimbingan konseling hanya menyentuh pendidikan formal saja dan belum masuk pada ranah pendidikan non formal.

\section{UCAPAN TERIMAKASIH}

Terimakasih kepada ketua dan seluruh jajaran sanggar kegiatan belajar kota sarang dan pusat kegiatan belajar masyarakat yang telah memberikan kesempatan untuk penerapan program bimbingan karir bagi siswa kesetaraan paket C pada tahun 2020

\section{DAFTAR PUSTAKA}

Anam, K. (2015). PENGARUH MEDIA PEMBELAJARAN TERHADAP MINAT BELAJAR SISWA PADA MATA PELAJARAN PAI DI SMP BANI MUQIMAN BANGKALAN. TADARUS: Jurnal Pendidikan Islam, 4 (2).

Asran, M. (2011). Pemetaan Masalah-Masalah Pendidikan Nonformal Di Kalimantan Barat: ( Implikasi Terhadap Peningkatan Akses Layanan Pendidikan Bermutu ). Jurnal Visi Ilmu Pendidikan, 5. https://doi.org/http://dx.doi.org/10.26418/jvip.v5i2.76

Blustein, D. (2006). The Psychology of Working. https://doi.org/10.4324/9780203935477

Duffy, R. D., Diemer, M. A., \& Jadidian, A. (2012). The Development and Initial Validation of the Work Volition Scale-Student Version. The Counseling Psychologist, 40(2), 291-319. https://doi.org/10.1177/0011000011417147

Faruqi, ahmad irfan al. (2016). MENINGKATKAN DAYA SERAP SISWA PADA PEMBELAJARAN GEOMETRI MENGGUNAKAN ICE BREAKINGMENINGKATKAN DAYA SERAP SISWA PADA PEMBELAJARAN GEOMETRI MENGGUNAKAN ICE BREAKING. Jurnal Riset Pendidikan, 2 (1).

Jadidian, A., \& Duffy, R. D. (2012). Work Volition, Career Decision Self-Efficacy, and Academic Satisfaction. Journal of Career Assessment, 20(2), 154-165. https://doi.org/10.1177/1069072711420851

Mulyawan, G. (2020). URGENSI BIMBINGAN KONSELING DALAM PENDIDIKAN NONFORMAL KHUSUSNYA PENDIDIKAN KESETARAAN (EQUIVALENCY EDUCATION). Jurnal Bimbingan Konseling Indonsesia, 5 (1).

Pramudi, H. (2015). Kemampuan pengambilan keputusan karier siswa kelas XI di SMA kutasari purbalingga. Jurnal Riset Mahasiswa Bimbingan Dan Konseling, 4 (4).

Walgito, B. (2005). bimbingan dan konseling (studi \& karir). yogyakarta: andi offset.

Yuliansyah, M., \& Jarkawi. (2019). PELATIHAN STRATEGIMENGANALISIS MASALAH SISWA DENGAN PSIKO-EDUKASI PADA SMK DI KABUPATEN BANJAR. DINAMISA - Jurnal Pengabdian Pada Masyarakat, 3 (2). 